\title{
THE BIRTH OF THE CIVIL RIGHTS MOVEMENT IN RUSSIA? Some Reactions to the Rise of Nationalism
}

\author{
Alexander Benifand \\ Centre for Refugee Studies, York University \\ \& Tanya Basok \\ Sociology/Anthropology, University of Windsor
}

In general, it is not easy for a new publication to survive in the former Soviet Union without receiving substantial subsidies. Dozens of new newspapers have gone bankrupt due to the high price of paper, bureaucratic bottlenecks and other problems. Yet nationalist newspapers do not seem to have experienced serious problems. They continue to grow. The Russian Society of Cooperation with Compatriots Abroad, for instance, produces 100,000 copies of their weekly newspaper, Russkii Vestnik. This newspaper is circulated by subscription and is also sold in the street. The magazine, Molodaya Gvardia, which can be purchased by subscription only, has a circulation of 300,000 .

State authorities have done virtually nothing to stop the spread of these and other mass-circulation publications, partly because it is extremely difficult for them to control production and circulation. In the first place, the true nature of a nationalist publications is often concealed when it is registered with the City Council's Committee on Publications. Descriptions submitted with applications can be so vague that officials find it difficult to detect the publication's real nationalist objectives. Moreover, once the publication receives a permit, there is no follow-up to insure that its contents correspond to the original description. True, the St. Petersburg City Council has created a Committee for the Defense of Freedom of the Press and the Mass Media which, among other things, is intended to control the spread of nationalist newspapers. But this committee has no staff, no money, and no clear mandate. ${ }^{1}$ Second, even though there is a law which criminalizes activities that incite ethnic conflict, it has not been enforced. ${ }^{2}$ Many agents of social control are inactive because the communication links between the militia and security organs have been broken. ${ }^{3}$ Third, even if the District Attorney were to shut down some newspapers, they could easily reappear under different names. This strategy is already being used by some organizations. For instance, an openly antisemitic newspaper, Moskovski Traktir, is simply a reincarnation of an earlier publication, Russkoe Voskresenie, which was in turn the reincarnation of Voskresenie. The Russian National Liberation Movement is behind all three publications. ${ }^{4}$ While Russian state authorities are unable to control antisemitic organizations and the hate literature they produce, a number of people have raised their voices in opposition to the rise of nationalist forces, their growing popularity and the fact that they act with impunity.

Whereas just a few months ago the mass media were silent about the threat such nationalist organizations pose, now some journalists sound alarmed. For instance, A. Prodkopalov, a Komsomolskaya Pravda correspondent, attended a meeting of the National Socialist Union (a fascist organization) and warned his readers that "no one took Hitler seriously" either. In his view, what makes the National Socialist Union particularly dangerous is that its three commercial enterprises offer it a substantial material base enabling it to hire loyal staff and pay them a salary as much as twice that earned by the average worker. ${ }^{5}$

The activities of the Russian Liberation Movement (ROD) have drawn the attention of several journalists. ${ }^{6}$ The objectives of this movement are: (1) to replace the present government by an exclusively Russian government; (2) to close the borders; (3) to grant citizenship to ethnic Russians only; (4) to create an exclusively Russian militia, security force and mobile military force. The latter could intervene quickly in case Russian minorities are attacked in other sovereign states of the former Soviet Union. The Republic of Russia they envision would include only Russian territories and exclude those which presently constitute nonRussian republics of the Russian Federation. The use of the swastika as their symbol clearly identifies them as Nazis. In his article on ROD, Murashko warns of the danger of being under the totalitarian rule of an "ambitious nationalist" force. ${ }^{7}$ For I. Tkachenko, the rise of such movements is an indication of the "revival of animal instincts." 8

O. Basilashvili, a Deputy of the Russian Parliament, wrote an open letter to the St. Petersburg District Attorney which was published in Smena. He drew attention to the dramatic increase in the activities of "national-patriotic movements" in St. Petersburg which, among other things, claim that it is sinful to socialize with Jews, who "desire Russian blood." Basilashvili cited the law which prohibits activities provoking ethnic violence and asked the District Attorney to explain his failure to take measures against the organization."

A number of journalists also ridicule the antisemitic press. $M$. Petrov, for instance, analyzes a number of nationalist newspapers, such as Russkie Vedomosti, Russkoe Delo, Russkii Vestnik, Nasha Rossia, and Otechestvo Russkie Vedomosti, for instance, is an ultra-nationalist newspaper published near Moscow. Its editorials include 
such titles as "The protocols of Zion" and "The Jewish question and its final solution." Other newspapers discussed in Petrov's piece publish similar articles. ${ }^{10}$

In the popular magazine, Ogonyok, Mark Deich, Radio Liberty's Moscow correspondent, attacked a number of antisemitic newspapers and journals, such as Russkoe Voskresenie, Molodaya Gvardia, Russkoe Delo, Pamyat and Volya Rossii. Russkoe Delo regularly accuses all Jews of being organized in a Mafia and of being "enemies of the people." It also mentions that it is not accidental that the February Revolution coincided with the Jewish holiday of Purim and the October Revolution with the birthday of the Jewish leader Trotsky. In Volya Rossii, one Soloukhin openly called for the destruction of all Jews. Deich warned in his article: "The history of the 20th century has clearly pointed out how easily the power of a few mad people over the minds of their fellow-citizens can turn a normal country into a schizophrenic state. ... Unfortunately, our present leaders fail to understand such simple facts while searching for 'good democratic elements' in Pamyat." 11 The editors of Ogonyok appealed to the state to take measures against "the plague which poses a threat to unfortunate Russia. ... If we suppress it today we won't give a new Hitler a chance to emerge." 12

The voices that have been raised against the spread of nationalism and its mass media are still very few. Until and unless these voices grow louder and force state authorities to respond, antisemitism and nationalism will offer false solutions tolarge masses of people who have become disenchanted with their present political leaders.

\section{Notes}

1. T. Zazorina "On pugaet, $i$ im ne strashno" ("He scares but they are not afraid"), Smena (13 March 1992).

2. The only exception was the prosecution of Smirnov Ostashvilli, who was one of the instigators of the pogrom against Jews in the Moscow Writers' Union House.
3. "Udarim po terroru ekspertnim sovetom" ("Let's attack terrorism: an expert's advice"), Vechernii Sankt Peterburg (31 January 1992).

4. P. Kholobaev "Moskovskii Traktir: tol'ko dlya evreev" ("Moskovskii Traktir: For Jews Only"), Komersant (6 February 1992).

5. A. Podkopalov "Natsisti raz'ezhayut poka na elektrichkakh" ("Nazis are still taking trams"), Komsomolskaya Pravda (8 February 1992).

6. Yu. Murashka "Kto sozdayot respubliku Rus?" ("Who is creating the republic of Russia?"), Sankt Peterburgskie Vedomosti (11 February 1992); I. Tkachenko, "Bezobidnaya svastika ili muzhskaya sut' RODa" ("Innocent swastika or the masculine nature of ROD"), Smena (28 January 1992); Yu. Murashka, "Zrelie muzhchini reshili sozdat' respubliku Rus" ("Mature men decided to create the republic of Russia"), Sankt Peterburgskie Vedomosti (28 January 1992).

7. Murashenko, "Who is creating the Republic of Russia," op. cit.

8. I. Tkachenko, "Innocent Swastika," op. cit.

9. O. Basilashvili, "Pochemu Molchit Zakon?" ("Why is the law silent?"), Smena (15 February 1992).

10. M. Petrov "Russkie otveti na evreiskie voprosi" ("Russian answers to Jewish questions"), Chas Pik (6 February 1992).

11. Mark Deich "Uzelki na 'Pamyat" ("Tie a knot on 'Pamyat'") Ogonyok (51: 1991): 6-8.

12. Editor's Note, Ogonyok (51: 1991): 8.

\section{Subscribe to}

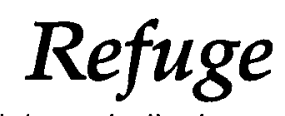

Canada's periodical on refugees

Now published ten times

a year

\section{Continued from page 6}

Yugoslav Refugees ...

\section{Notes}

1. This expression was used by Branko Horvat in his communication at the meeting "Das Europäische Jugoslawien," Reichstag (Berlin: 1314 September 1991).

2. This conflict was an unprecedented welcome opportunity for Germany to demonstrate its unwillingness to further tolerate the discrepancy between economic and political power.

3. Borba (24 March 1992).

4. Yugofax (3 February 1991).

5. Die Tageszeitung (30 March 1992).

6. Vreme (6 August 1991).

7. Whether the applicant for this privileged treatment is considered to be from the territory of Croatia, or whether only Croatians are considered to be beneficiaries, is unfortunately left to the arbitrary decision of the local authorities.

8. UNHCR Update (3 December 1991).

9. Danaa (6 August 1991).

10. Silvano Bolcic, "Citizens sans frontiers," Yugofax (28 December 1991).

11. Hannah Arendt, The Origins of Totalitarianism (New York and London: Harcourt, Brace, Jovanovich, 1979): 270.

12. Zdenka Milivojevic "Research on displaced persons from Croatia, 1991," paper presented at a conference on Mass Migrations in Europe (Vienna: 5-7 March 1992).

13. UNHCR Update (3 December 1991).

14. Yugofax (3 February 1992).

15. Vreme (23 March 1992).

16. Grobnica za Miroslava Milenkovica (Belgrade: 1991).

17. Vreme (23 December 1991).

18. Sentences meted out to deserters in recent court cases in the towns of Zajecar and Kraljevo, Serbia, range from 1000-10,000 Dinar fines to 30 days of prison. Borba (24 March 1992 and 31 March 1992).

19.Vreme (23 March 1992). 